\title{
ПЕРЕХІД ДОРОЖНЬОГО ГОСПОДАРСТВА НА РИНКОВІ МЕТОДИ ГОСПОДАРЮВАННЯ ПРИ ДОТРИМАННІ ЕКОЛОГІЧНОЇ БЕЗПЕКИ
}

\author{
Юрченко О.В., к.е.н., доцент
}

Сумський національний аграрний університет

Деділова Т.В., к.е.н., доцент

\section{Харківський національний автомобільно-дорожній університет}

Постановка проблеми. Поряд 3 підвищенням екологічних вимог до проектування, будівництва, ремонту та утриманню автомобільних доріг повинні бути вжиті заходи щодо вдосконалення самих транспортних засобів 3 метою приведення їх у відповідність до вимог найжорсткіших зарубіжних стандартів, а також підвищенню якості використовуваних видів палива.

Автомобільні дороги загального користування належать до єдиної всеукраїнської транспортної системи, призначенням якої $\epsilon$ задоволення економікою країни потреби в пасажирських та вантажних перевезеннях автомобільним транспортом. Також це значним чином впливає на ії соціальний розвиток, з'єднує міжнародні транспортні коридори 3 національною транспортною мережею, інтегрує Україну до європейського співтовариства.

Щорічно, станом на початок року, 97\% доріг, відповідно до діючих міжремонтних періодів, потребують капітального ремонту: $88 \%$ доріг спроектовано під навантаження на вісь автомобіля максимум у 6 тон., тоді як сучасний вантажний автотранспорт має навантаження 11,5 тони на вісь. При цьому, за оцінкою експертів, 30-40\% великовантажних автомобілів виїжджають на дороги 3 наднормативним завантаженням. У результаті доводиться констатувати збільшену «втому» українських доріг [1]. 
Аналіз остатніх досліджень і публікацій. Дослідженню проблеми економічної ефективності в контексті екологічної безпеки функціонування підприємств присвячені фундаментальні дослідження таких вчених, як Є. Прусенко [2], І. Лазаришина [3], М. Абрамчук, І. Кобушко [4], О. Храпаль [5], Г. Гончаренко [6] та ін.

Невирішені складові загальної проблеми. Разом 3 тим багато аспектів досліджуваної проблеми, особливо економічного механізму підтримки екологічної безпеки дорожнього господарства при функціонуванні в ринкових умовах, залишаються невирішеними.

Формулювання цілей статті. Мета статті полягає в обгрунтуванні та розробці теоретико-методичних засад забезпечення функціонування дорожнього господарства України та його розвитку за ринкових умов шляхом дослідження прямого впливу вантажного автотранспорту на стан автодоріг й опосередкованого його впливу на довкілля.

Виклад основного матеріалу дослідження. Завчасне руйнування дорожнього покриття та порушення умов експлуатації автомобільних шляхів України в багатьох випадках зумовлено порушенням умов щодо проїзду транспортних засобів 3 великим навантаженням на вісь. Проектні умови будівництва та експлуатації автомобільних доріг як інженерних споруджень, що були закладені в основу української дорожньо-транспортної мережі ще за радянських часів, на сучасному етапі кількісного та якісного розвитку автомобільного транспорту не витримують збільшення вантажопідйомності та інтенсивності руху автомобілів. У сільськогосподарських районах на дорогах можливий рух тракторних поїздів з кількома причепами. Допускається також проїзд мотоциклів і сільськогосподарських машин на гумових шинах. Гусеничні машини, що руйнують дорожній одяг, і кінні візки повинні їхати по паралельних грунтових дорогах або по спеціально влаштованих тракторних шляхах. Незадовільний стан автомобільних доріг у кілька разів збільшує викиди шкідливих речовин в атмосферу, чим украй несприятливо впливає на довкілля. За умов зниження швидкостей руху й припинення його у місцях 
дефектів дороги обсяг викиду окису вуглецю збільшується в декілька разів у порівнянні з викидами при оптимальних швидкостях руху (близько 70 км/год.). За цих умов підвищення якості дорожньої мережі $є$ ключовим фактором покращення стану навколишнього середовища. Однак, у чинних нормативних документах практично формально викладені вимоги до екологічної безпеки, яких їх слід дотримуватись при проектуванні й експлуатації доріг, відсутній цілий ряд стандартів з виміру забруднення, що негативно відображується на стані екологічної ситуації в зоні впливу автомобільних доріг.

3 аналізу [7] видно, що лише 26\% доріг здатні витримувати великовагові вантажні автомобілі. Переважна більшість наших українських доріг здатна витримувати навантаження не більше 7 тон на вісь. 40\% доріг вже повністю знищено, а капітальний ремонт потрібен практично «з нуля». Решта доріг потребує негайного поточного ремонту та суворого дотримання норм вагового навантаження на вісь (табл. 1).

Таблиия 1

Нормативне навантаження автодороги автотранспортом

\begin{tabular}{|l|c|c|c|}
\hline \multicolumn{1}{|c|}{ Категорія дороги } & I & II-III & IV-V \\
\hline Товщина полотна, см & 20 & $8-12$ & 5 \\
\hline Протяжність доріг, км & $2700(2 \%)$ & $38700(24 \%)$ & $118000(74 \%)$ \\
\hline Навантаження на вісь, т & 11,5 & 10,6 & 7,0 \\
\hline Максимальна вага авто, т & 40 & 36 & 24 \\
\hline
\end{tabular}

Досерело: складено авторами на основі [7]

В результаті проведеного дослідження можна запропонувати удосконалення еколого-економічної сутності категорії «втома автодороги» та іiі впливу на екологічну безпеку в дорожньому господарстві через коефіцієнт втоми автодоріг. Під коефіціснтом втоми доріг (В) будемо розуміти відношення маси вантажу великовантажних автомобілів (А) до проектного навантаження (П) за певний проміжок часу. При рівності коефіцієнта втоми дороги (В) одиниці або перевищенні даного значення виникає таке поняття, як «втома автодороги». В цілому збільшення «втоми» українських доріг (надпроектне навантаження) призводить до руйнування не лише їх покриття, а й фундаменту. 
Саме тому, вважаємо за необхідне посилення відповідальності за порушення вагових норм за категоріями доріг, підгрунтям якого повинні стати заходи, підкріплені відповідним нормативно-правовим забезпеченням. Зокрема, до таких можна віднести: повну заборону руху авто вагою більше 40 тон/24 тон для подільних вантажів. Введення обмеження у 7 тон на вісь або 24 тони загальної ваги для доріг місцевого значення (ухвалено КМУ від 21/10/2015, №869 [8]); встановлення справедливих штрафів за порушення вагових норм (17-85 тис. грн) з конфіскацією авто за повторне порушення протягом кварталу. Або збільшити їх ще більше, до рівня європейських країн (Польща 1,5 тис. євро, Німеччина - 10 тис. євро) (проект 3У [9]); введення відповідальності компанії, що завантажує авто, за перевагу, за умови, що не було проведено контрольне зважування у присутності перевізника (проект ЗУ [9]) тощо. Захист доріг від передчасного руйнування при порушення вагових норм (табл. 2) передбачає: створення нової некорумпованої дорожньої інспекції (Укртрансбезпека) в складі 70-100 екіпажів, обладнаних відеореєстраторами 3 трансляцією їх роботи в мережі Інтернет; введення в дію мережі із 200 автоматичних вагових комплексів «зважування на ходу»; суттєве підвищення штрафів за порушення вагових норм (мін. штраф 17 тис. грн., конфіскація авто за повторне порушення протягом року); приведення у відповідність вагових норм до реальної здатності доріг (7 тон на вісь на дорогах місцевого значення); заборона перевезень подільних вантажів 3 перевищенням існуючих норм [10].

Табличяя 2

Моніторинг сучасного стану дорожнього господарства (розробка авторів)

\begin{tabular}{|l|l|}
\hline \multicolumn{1}{|c|}{ Причини поточного стану } & \multicolumn{1}{|c|}{ Необхідні дії } \\
\hline Критичне недофінансування & Реформування системи фінансування \\
\hline Застаріла система управління & Децентралізація системи управління \\
\hline Неефективний контроль якості & Гарантії якості дорожніх робіт \\
\hline Не працює контроль вагових норм & Захист від порушників вагових норм \\
\hline \multicolumn{2}{|c|}{ Очікувані результати: } \\
\hline \multicolumn{2}{|c|}{ Зростання міжнародних транзитних перевезень автомобільним транспортом } \\
\hline \multicolumn{2}{|c|}{ Відновлення дорожніх робіт, дотримання міжремонтних інтервалів } \\
\hline \multicolumn{2}{|c|}{ Розвиток економіки, створення нових робочих місць, розвиток туризму } \\
\hline Задоволення потреб суспільства в якісних автомобільних дорогах \\
\hline
\end{tabular}


При недотриманні вимог по утриманню автомобільних доріг в нормативному стані до винних можуть бути застосовані адміністративні заходи (табл. 3).

Табличя 3

Адміністративні заходи, спрямовані на підтримку еколого-економічної безпеки дорожнього господарства (складено авторами на основі $[1,11])$

\begin{tabular}{|c|c|}
\hline Адміністративний вплив & Сутність, прояви \\
\hline Прямий & $\begin{array}{l}\text { Характеризується наявністю приписів, які мають обов’язків } \\
\text { характер. До основних проявів прямого впливу можна віднести: } \\
\text { державну реєстрацію, ліцензування, надання відповідних } \\
\text { дозволів, управління об’єктами державної власності, } \\
\text { встановлення стандартів, здійснення контролю та нагляду, } \\
\text { застосування відповідальності до порушників тощо. }\end{array}$ \\
\hline Непрямий вплив & $\begin{array}{l}\text { Відноситься сукупність економічних засобів впливу на } \\
\text { підприємницькі відносини (наприклад, податкова політика, } \\
\text { регулювання цін, фінансово-кредитна політика, державні } \\
\text { програми, державні контракти та замовлення тощо). }\end{array}$ \\
\hline \multicolumn{2}{|c|}{$\begin{array}{l}\text { Вважаємо, що до найбільш ефективних методів адміністративно-правового регулювання } \\
\text { господарської діяльності необхідно віднести методи, пов'язані з державною реєстрацією, } \\
\text { ліцензуванням та наданням дозволів, встановленням стандартів, державними } \\
\text { замовленнями, контролем та наглядом, підтримкою суб'єктів господарювання }\end{array}$} \\
\hline
\end{tabular}

Дорожнє господарство - одна 3 не багатьох сфер економіки, що оперувала власним джерелом фінансування програм робіт з будівництва, реконструкції та утриманню автомобільних доріг, єдиним механізмом акумулювання і розподілу фінансових ресурсів, розвиненою мережею споживачів. За ринкових умов зміна джерел фінансування проектів дорожнього будівництва призводить до суттєвих змін в організації дорожнього господарства на кожній із фаз його життєвого циклу. Діюча структура управління дорожнім господарством потребує подальшого реформування (рис. 1), (табл. 4).

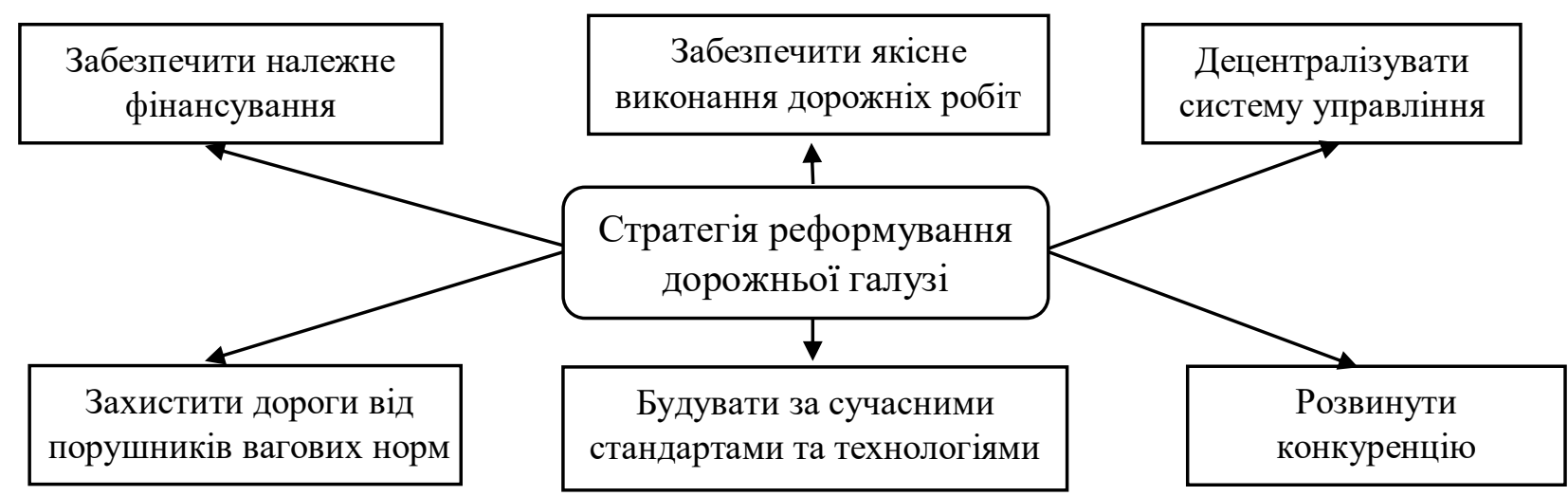

Рис. 1. Стратегія реформування дорожньої галузі (розробка авторів) 


\section{Основні напрями з реалізації заходів з реформування} дорожньої галузі України

\begin{tabular}{|l|l|}
\hline \multicolumn{1}{|c|}{ Напрям } & \multicolumn{1}{|c|}{ Зміст заходу } \\
\hline децентралізація системи & $\begin{array}{l}\text { Передача доріг місцевого значення разом з джерелами } \\
\text { фінансування місцевим органам влади. } \\
\text { Децентралізація експлуатаційних потужностей шляхом } \\
\text { ліквідації ПАТ «ДАК «Автомобільні дороги України» та } \\
\text { передачі Облавтодорів на місцевий рівень. }\end{array}$ \\
\hline $\begin{array}{l}\text { Забезпечення достатнього } \\
\text { фінансування }\end{array}$ & Створення нової Служби Державних Доріг, шляхом \\
укрупнення САДів у 8-10 Упродорів, шо є територіальними \\
підрозділами СДД \\
Поступовий допуск на ринок експлуатації приватних \\
підрядників шляхом аутсорсингу цих робіт, запровадивши \\
контракти з виплатами за кінцевим результатом (ОРRС). \\
Запровадження довгострокових (5-10 років) договорів на \\
будівництво та одночасну подальшу експлуатацію дороги.
\end{tabular}

Джерело: розробка авторів

3 цією метою в Україні розроблені фактично всі необхідні інструменти для створення ефективної системи реформування дорожньої галузі, яка дозволить: зменшити витрати коштів та часу на прийняття ефективних управлінських рішень щодо забезпечення безпечних умов руху на існуючих автомобільних дорогах; оптимально спрогнозувати необхідні фінансові ресурси для утримання мережі доріг в межах кожної області; об'єктивно інформувати всі зацікавлені організації та суспільство про стан автомобільних доріг та дорожню обстановку [11].

Висновки 3 проведеного дослідження. Таким чином, за результатами проведеного аналізу визначено високий ступінь взаємодії автомобільних доріг 3 навколишнім середовищем, який переважно має негативний характер впливу на екологічну безпеку в цілому. В свою чергу, існує нерозривний екологічний 
ланцюг: «Дорога - довкілля - якість життя населення». В цьому контексті стимулювання розвитку дорожнього господарства повинно проводитися за декількома напрямкам: розробка та затвердження в установленому порядку Програми розвитку дорожнього господарства України; проведення аудиту українських стандартів з проектування, будівництва, ремонту та утримання доріг на їх відповідність європейським та адаптування сучасної нормативної базу до європейських стандартів; створення єдиної інформаційно-аналітичної системи управління автомобільними дорогами загального користування 3 доступом громадськості до інформації щодо стану та екологічної безпеки автомобільних доріг; впровадження системи автоматизованого контролю за дотриманням норм вагового навантаження для автомобільних доріг загального користування.

\section{Перелік посилань}

1. Самісько T. О. Етапи становлення i розвитку дорожнього господарства України. Вісті Автомобільно-дорожнього інституту. 2008. № 2. C. $78-83$.

2. Гончаренко Ф. П. Прусенко Є. Д., Скорченко В. Ф. Експлуатаційне утримання та ремонт автомобільних доріг за складних погодних та екологічних умов. Київ, 1999. 264 с.

3. Лазаришина I., Солодка Л. Економіко-екологічне обгрунтування впливу автомобільних доріг на довкілля : сайт URL : http://irbis-nbuv.gov.ua (дата звернення : 29.11.2018).

4. Абрамчук М. Ю., Кобушко I. М. Система управління забезпеченням екологічної безпеки: організаційні, економічні та фінансові аспекти : сайт URL : http://business-inform.net/export_pdf/business-inform-2014-10_0-pages-242_248.pdf (дата звернення : 29.11.2018)

5. Храпаль О. В. Еколого-економічні проблеми технологічної системи «Автомобільна дорога - навколишнє середовище» Вісник Сумського НАУ. Сер. «Фінанси і кредит». 2003. Вип. 1 (14). С. 291-294. 
6. Гончаренко Г. Є. Екологічна безпека як складова екологічного правопорядку сайт

URL

https://dspace.udpu.edu.ua/jspui/bitstream/6789/4335/1/\%D0\%B3\%D0\%BE\%D0\%B D\%D1\%87\%D0\%B0\%D1\%80\%D0\%B5\%D0\%BD\%D0\%BA\%D0\%BE.pdf (дата звернення : 30.11.2018)

7. Споруди транспорту. Автомобільні дороги. ДБН В.2.3-4-2000. (чинний від 01.07.2000) : Державні будівельні норми України. К. : Державний комітет будівництва, архітектури та житлової політики України, 2000. 114 с.

8. Постанова Кабінету Міністрів України «Про внесення змін до пункту 22.5 Правил дорожнього руху» (№869 від 21.10.2015р.) : сайт URL: http://zakon.rada.gov.ua/laws/show/869-2015-\%D0\%BF (дата звернення : 01.12.2018)

9. Проект Закону про внесення змін до Закону України «Про автомобільний транспорт» (щодо дотримання учасниками ринку автомобільних вантажних перевезень норм законодавства в частині вагових та габаритних параметрів транспортних засобів) (№6644 від 23.06.2017р.) : сайт URL: http://w1.c1.rada.gov.ua/pls/zweb2/webproc4_1?pf3511=62128 : (дата звернення : 01.12.2018)

10. Солодкий В. О., Солодка Л. О. Перспективи розвитку дорожнього господарства України : сайт URL http://www.rusnauka.com/7_NND_2009/Economics/42565.doc.htm : (дата звернення : 01.12.2018)

11. Юрченко О. В. Дослідження основних еколого-економічних проблем дорожньої галузі України. Молодь та інновації : Міжнародна науковопрактична конференція, 27-29.05.2015 р. : тези доп. Горки, Республіка Білорусь, 2015. С. 180-184.

\section{References}

1. Samis"ko, T. O. (2008), "Stages of formation and development of road economy of Ukraine" ["Etapy` stanovlennya i rozvy`tku dorozhn`ogo gospodarstva Ukrayiny'"], Lead the automobile and road institute, No. 2, P. 78-83. 
2. Goncharenko, F. P., Prusenko, E. D., Skorchenko, V. F. (1999), Maintenance and maintenance of highways in difficult weather and environmental conditions [Ekspluatacijne utry`mannya ta remont avtomobil 'ny`x dorig za skladny`x pogodny`x ta ekologichny`x umov], Kyiv, 264 p.

3. Lazarishina, I., Solodka, L. "Economic and environmental justification of the impact of highways on the environment" ["Ekonomiko-ekologichne obg`runtuvannya vply`vu avtomobil`ny`x dorig na dovkillya”], available at : http://irbis-nbuv.gov.ua (last accessed 29.11.2018).

4. Abramchuk, M. Yu., Kobushko, I. M. "Management System for Environmental Safety: Organizational, Economic and Financial Aspects" ["Sy`stema upravlinnya zabezpechennyam ekologichnoyi bezpeky` organizacijni, ekonomichni ta finansovi aspekty'”], available at : http://business-inform.net/export_pdf/businessinform-2014-10_0-pages-242_248.pdf (last accessed 29.11.2018).

5. Khrapal, O. V. (2003) "Ecological-economic problems of the technological system "Road - the environment" ["Ekologo-ekonomichni problemy” texnologichnoyi sy`stemy` “Avtomobil`na doroga - navkoly`shnye seredovy`she”], Visnyk Sumy NAU. Series "Finance and Credit", No. 1 (14), P. 291-294.

6. Goncharenko, G. E. "Ecological safety as a component of environmental law and order" ["Ekologichna bezpeka yak skladova ekologichnogo pravoporyadku"], available at

https://dspace.udpu.edu.ua/jspui/bitstream/6789/4335/1/\%D0\%B3\%D0\%BE\%D0\%B D\%D1\%87\%D0\%B0\%D1\%80\%D0\%B5\%D0\%BD\%D0\%BA\%D0\%BE.pdf (last accessed 30.11.2018).

7. State building regulations of Ukraine (2000), Constructions of transport. Roads. DBN V. 2.3-4-2000. Effective from 01.07.2000 [Sporudy transportu. Avtomobil`ni dorogy`. DBN V. 2.3-4-2000. Chy`nny`j vid 01.07.2000)], State Committee for Construction, Architecture and Housing Policy of Ukraine, Kyiv, $114 \mathrm{p}$.

8. Resolution of the Cabinet of Ministers of Ukraine (2015), "On Amendments to Clause 22.5 of the Road Traffic Rules". No. 869. Effective from 21.10.2015 ["Pro 
vnesennya zmin do punktu 22.5 Pravy`l dorozhn`ogo ruxu”. No. 869. Chy`nny`j vid 21.10.2015], available at : http://zakon.rada.gov.ua/laws/show/869-2015-\%D0\%BF (last accessed 01.12.2018).

9. Draft Law on Amendments to the Law of Ukraine (2017), "On Road Transport". No. 6644 of 23.06.2017 (regarding the observance by the participants of the road freight transport market of norms of legislation regarding the weight and dimensional parameters of vehicles)" ["Pro avtomobil`ny`j transport» (shhodo dotry`mannya uchasny`kamy`ry`nku avtomobil`ny`x vantazhny`x perevezen`norm zakonodavstva $\mathrm{v}$ chasty`ni vagovy`x ta gabary`tny`x parametriv transportny`x zasobiv)". No. 6644 of 23.06.2017], available at : http://w1.c1.rada.gov.ua/pls/zweb2/webproc4_1?pf3511=62128 (last accessed 01.12.2018).

10. Solodky, V. O., Solodka, L. O. "Prospects for the development of road economy of Ukraine" ["Perspekty`vy' rozvy`tku dorozhn`ogo gospodarstva Ukrayiny"'], available at

http://www.rusnauka.com/7_NND_2009/Economics/42565.doc.htm (last accessed 01.12.2018).

11. Yurchenko, O. V. (2015) "Research of the main ecological and economic problems of the road industry of Ukraine : theses of additional" ["Doslidzhennya osnovny`x ekologo-ekonomichny`x problem dorozhn`oyi galuzi Ukrayiny` : tezy` dop."]. Youth and Innovation: International Scientific and Practical Conference, $27-$ 29.05.2015, Gorki, Republic of Belarus, P. 180-184. 
Юрченко О.В., Деділова Т.В. ПЕРЕХІД ДОРОЖНЬОГО ГОСПОДАРСТВА НА РИНКОВІ МЕТОДИ ГОСПОДАРЮВАННЯ ПРИ ДОТРИМАННІ ЕКОЛОГІЧНОЇ БЕЗПЕКИ

Mema. Обгрунтування та розробка теоретико-методичних засад забезпечення функціонування дорожнього господарства України та його розвитку за ринкових умов шляхом дослідження прямого впливу вантажного автотранспорту на стан автодоріг й опосередкованого його впливу на довкілля. Методика дослідження. В роботі використано наступні методи: діалектичний метод (при виявленні причинно-наслідкового зв'язку економічних і екологічних процесів); аналітичний метод (для систематизації інформації щодо нормативного навантаження автодороги автомобільним транспортом); спостереження та узагальнення (для розробки рекомендацій щодо стратегії реформування дорожньої галузі). Результати. У дослідженні визначено роль еколого-економічної безпеки в системі стратегії розвитку дорожнього господарства України в контексті реалізації процесу поліпшення стану довкілля в цілому. Акцентовано увагу на значені автоматизованої системи моніторингу за станом доріг та фінансуванні охорони природного довкілля в Україні. Досліджено проблеми природокористування, пов'язані з експлуатацією автомобільних доріг, і встановлено шляхи їх рішення. Запропоновано основні напрями 3 реалізації заходів 3 реформування дорожньої галузі України. Наукова новизна. Отримав подальший розвиток теоретико-методичний підхід до забезпечення функціонування дорожнього господарства України шляхом дослідження прямого впливу вантажного автотранспорту на стан автомобільних доріг й опосередкованого його впливу на довкілля, що, на відміну від існуючих підходів, дозволяє встановлювати основні напрями 3 реалізації заходів 3 реформування дорожньої галузі України 3 урахуванням екологічного фактору. Практична значущість. Результати дослідження можуть слугувати методичними рекомендаціями органам державного управління при розробці регіональних програм з будівництва та експлуатації автодоріг, розвитку транспортної мережі регіону.

Ключові слова: дорожнє господарство, автомобільна дорога, вантажний автотранспорт, втома доріг, екологічна безпека, реформування.

\section{Юрченко О. В., Дедилова Т. В. ПЕРЕХОД ДОРОЖНОГО ХОЗЯЙСТВА НА РЫНОЧНЫЕ МЕТОДЫ ХОЗЯЙСТВОВАНИЯ С СОБЛЮДЕНИЕМ ЭКОЛОГИЧЕСКОЙ БЕЗОПАСНОСТИ}

Цель. Обоснование и разработка теоретико-методических основ обеспечения функционирования дорожного хозяйства Украины и его развития в рыночных условиях путем исследования прямого влияния грузового автотранспорта на состояние автодорог и косвенного его влияния на окружающую среду. Методика исследования. В работе использованы следующие методы: диалектический метод (при выявлении причинноследственной связи экономических и экологических процессов); аналитический метод (для систематизации информацию о нормативной нагрузке на автодорогу автомобильным транспортом), наблюдение и обобщение (для разработки 
рекомендаций по стратегии реформирования дорожной отрасли). Результаты. В исследовании определена роль эколого-экономической безопасности в системе стратегии развития дорожного хозяйства Украины в контексте реализации процесса улучшения состояния окружающей среды в целом. Акцентировано внимание на значении автоматизированной системы мониторинга за состоянием дорог и финансировании охраны окружающей природной среды в Украине. Исследованы проблемы природопользования, связанные с эксплуатацией автомобильных дорог, и установлены пути их решения. Предложены основные направления по реализации мероприятий по реформированию дорожной отрасли Украины. Научная новизна. Получил дальнейшее развитие теоретико-методический подход к обеспечению функционирования дорожного хозяйства Украины путем исследования прямого влияния грузового автотранспорта на состояние автомобильных дорог и косвенного его влияния на окружающую среду, что, в отличие от существующих подходов, позволяет устанавливать основные направления по реализации мероприятий по реформированию дорожной отрасли Украины с учетом экологического фактора. Практическая значимость. Результаты исследования могут служить методическими рекомендациями органам государственного управления при разработке региональных программ по строительству и эксплуатации автодорог, развития транспортной сети региона.

Ключевые слова: дорожное хозяйство, автомобильная дорога грузовой автотранспорт, усталость дорог, экологическая безопасность, реформирование.

\section{Yurchenko O., Dedilova T. THE TRANSFER OF ROAD ECONOMY TO MARKET METHODS OF MANAGEMENT IN COMPLIANCE WITH ENVIRONMENTAL SAFETY}

Purpose. The theoretical and methodical bases of functioning of the road economy of Ukraine and its development in market conditions by studying the direct impact of freight vehicles on state highways and its indirect impact on the environment were substantiationed. Methodology of research. The following methods were used in the research. The dialectical method was used for identifying causal link of economic and environmental processes. The analytical method was applied for systematization of information about normative loading of a road by road transport. The observation and generalization were relevance for the development of recommendations for a road reforming strategy. Findings. The article describes the role of ecological and economic safety in the system development strategy road of Ukraine; the process of improving the environment; importance of automated system monitoring of roads; financing protection of the environment in Ukraine. The problems of nature and the way of their decision, ecological and economic mechanisms for regulating the ecological state of natural resources, trends in ecological and economic security have analyzed. Originality. The theoretical and methodological approach to the functioning of the road economy of Ukraine has been further developed by studying the direct impact of freight vehicles on the condition of 
highways and indirectly on its impact on the environment. It, unlike existing approaches, allows us to establish the main directions of implementation of measures on the road economy reform in Ukraine taking into account the environmental factor. Practical value. The results of the research can be used as guidelines for the public administration in the development of regional programs for the construction and operation maintenance of roads, development of transport network of the region.

Key words: road economy, road, freight vehicles, road fatigue, ecological safety, reforming.

Юрченко Оксана Вікторівна - кандидат економічних наук, Сумський національний аграрний університет, доцент кафедри будівельного виробництва, м. Суми, Україна; e-mail: vitaboris1979@ukr.net. Моб. 066-716-76-80.

Юрченко Оксана Викторовна - кандидат экономических наук, Сумской национальный аграрный университет, доцент кафедры строительного производства., г. Сумы, Украина.

Yurchenko Oksana - Candidate of Science (Economics), Sumy National Agrarian University, Associate Professor at the Department of Construction, Sumy, Ukraine.

Деділова Тетяна Вікторівна - кандидат економічних наук, доцент, Харківський національний автомобільно-дорожній університет, доцент кафедри економіки і підприємництва, м. Харків, Україна; e-mail: dedilova @ukr.net; ORCID ID: https://orcid.org/0000-0002-3924-979Х. Моб. 050-281-83-28.

Дедилова Татьяна Викторовна - кандидат экономических наук, доцент, Харьковский национальный автомобильно-дорожный университет, доцент кафедры экономики и предпринимательства, г. Харьков, Украина.

Dedilova Tetiana - Candidate of Science (Economics), Associate Professor, Kharkiv National Automobile and Highway University, Associate Professor at the Department of Economics and Entrepreneurship, Kharkiv, Ukraine. 